\title{
The use of Edmodo in academic writing education ${ }^{* *}$
}

\section{APA Citation:}

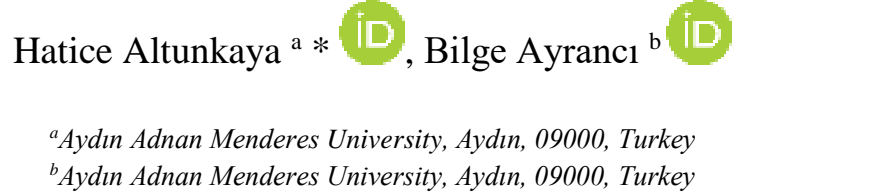

Altunkaya, H., \& Ayranc1, B. (2020). The use of Edmodo in academic writing education. Journal of Language and Linguistic Studies, 16(1), 89-103.Doi: $10.17263 /$ jlls. 712659

Submission Date:20/12/2019

Acceptance Date:12/03/2020

\begin{abstract}
Academic writing intends to enunciate research findings in a certain discipline within the scientific world. The contents of the Turkish Language II course, offered in the spring semesters of the teacher training programs in education faculties, are based on academic writing skills education. The present study aims to determine the effects of Edmodo assisted academic writing education on student achievement. A quasi-experimental design with a pretest and post-test control group was used for the quantitative part of the present study, which employed a mixed research design. In the qualitative part, student opinions on Edmodo assisted education were retreived via a semistructured interview form. The study group consisted of 108 students, 54 in the experimental and 54 in the control group, who were enrolled in the spring semester of the 2018-2019 academic year in the Guidance and Psychological Counseling Program of a state university. The quantitative data was analyzed via SPSS and descriptive analysis was used to interpret qualitative data. The findings of the quantitative analysis indicated that the experimental group had higher academic writing achievement compared to the control group. The qualitative findings also revealed that students considered Edmodo assisted academic writing education useful.
\end{abstract}

(C) 2020 JLLS and the Authors - Published by JLLS.

Keywords: edmodo, academic writing, teacher training program, guidance and psychological counseling program.

\section{Introduction}

Academic writing intends to enunciate research findings in a certain discipline within the scientific world. "Academic writing is the objective description of the research findings in a scientific field. The intended audience of academic writing, which aims to publicize the contribution of a newly conducted research to the scientific world, is composed of individuals who work in the relevant domain" (Altunkaya, 2019, p. 133). Academic writing is a genre resorted by individuals who could comment within the scope of a discipline and depends on various principles. The individuals who engage in the act of academic writing first need to have a thesis, and further, they need to have adequate preliminary knowledge in the particular domain pertaining to their thesis, to have good knowledge on and to acknowledge previous work in the relevant research domain, and to ground their writing on scientific basis.

\footnotetext{
${ }^{*}$ Corresponding author. Tel.: +90-2562137432

E-mail address: hatice.altunkaya@adu.edu.tr
} 
Academic reading, listening and writing are among the basic learning skills in higher education. Preservice teachers should acquire academic writing skills in the Turkish Language II course based on the faculty of education, freshmen year second semester higher education curriculum. Various studies on the acquisition of this skill indicated several acquisition problems. Frenc (2016) reported that especially freahmen struggled with and failed due to their "poor writing skills" based on the statements of related faculty members; and thus, coping with unaccustomed higher education academic writing applications was vital for the achievements, skills acquisition and development of freshmen students. Murray and Thow (2014) reported that there are several methods for the act of writing; however, academic writing is a deliberate act; and therefore, it is rather a behavior. As described in the common definition of education, academic writing education entails a deliberate change in behavior in the desired direction to ensure that the students acquire adequate academic writing skills.

Various studies (Gardner, 2014; Arneback, Englund \& Solbrekke, 2016) reported that academic writing experiences in teacher training were strongly influenced by the education of the students, their previous writing experiences, and their views as teacher candidates. The writing rules for all sections of an academic text and ethical principles in academic writing should be instructed in detail for the preservice teachers to acquire academic writing skills. Murray (1987, cited in Tok, 2012: p. 25) reported the stages of the academic writing process as pre-writing, planning, drafting, reflection, peer and teacher review, editing, additional research and generation of ideas, final reading and publication. Similar stages are included in the Turkish Council of Higher Education Teacher Training Curriculum as section topics. The Turkish Council of Higher Education suggests that the students should acquire necessary academic writing skills through the Turkish Language II course in the Teacher Training Undergraduate Programs (2018). The course content recommended by the Council focuses on:

Characteristics of academic language and texts; use of definitions, concepts and terms in academic writing; objective and subjective expressions; structure and types of academic texts (articles, reports, scientific abstracts etc.); writing arguments and proposals (verifying, supporting or opposing an idea); formal characteristics of scientific reports and articles; the stages of report writing; explanation, discussion, establishing relationships between texts, referencing (citations, footnotes, bibliography); writing a title, abstracting, writing keywords; ethical principles to be considered in scientific texts; academic text writing practices (CHE, 2018, p. 5).

It is the responsibility of the faculty members to ascertain that pre-service teachers transform the above-mentioned achievements depicted in the curriculum into behavior. It could be suggested that utilization of modern educational technologies and approaches could be beneficial in this educational process.

\subsection{Literature review / Theoretical background}

\subsubsection{Use of Edmodo in Academic Writing Education}

Currently, various blogs, such as Whatsapp, Facebook, Instagram, Google Classroom, Edmodo and Twitter are being used in education environments, due to the developments in technology. Edmodo was founded in 2008 by Nic Borg and Jeff O'Hara in Illinois, Chicago. In 2010, the application was developed further to enable the mutual cooperation between teachers and students. Trust (2012) described Edmodo as an interactive platform for mutual collaboration and social networking between teachers and students. Ali (2015, p. 40) stated that Edmodo provided users with features such as uploading profile photos, sharing documents, links and videos and such uploaded materials could be stored in the library, be re-accessed and shared with others.

Edmodo, a tool that enables teachers, students and parents to collaborate during the education process, provides the opportunity to upload, store and share various files and videos that are appropriate 
to the content of the course, though a library system. Edmodo, which offers interactive learning in leisure time outside the limited class hours, is considered as a useful learning and teaching tool since it also provides an opportunity for the parents to track the learning progress of their children. Edmodo assists teachers in uploading materials related to course contents into the system and in holding exams for students. Furthermore, teachers are capable of giving the students assignments with a deadline and students can submit their completed assignments through uploading them to the system by using own accounts. Thus, teachers evaluate the completed student assignments and provide feedback and ensure more effective and permanent learning. The students, therefore, become capable of a more effective learning through overcoming their insufficiencies due to the received feedback. Wallace (2014) states that Edmodo is a pedagogical and cooperative communication system. Carolan and Kyppö (2015) argued that traditional approach in collecting student work and providing feedback for each work takes a long time and students could forget the subject they studied by the time they received the feedback, yet online feedback through Edmodo allowed students to make changes in their drafts while the subject is still in focus. Several researchers indicated the benefits of using Edmodo in writing education as follows: Edmodo facilitated rapid access to writing materials and assignments, students could develop various approaches, methods or techniques through using Edmodo in order to further organize their writing, Edmodo provided evaluation and feedback opportunities for teachers in assessing student writings, students could improve their writing with respect to teacher comments and feedback, and Edmodo increased student interest in writing (Stroud, 2010; Balasubramanian, Jaykumar, \& Fukey, 2014; Purnawarman, Susilawati, \& Sundayana, 2016; Shams-Abadi, Ahmadi, \& Mehrdad, 2015).

In literature review, there exist various studies that utilized Edmodo for educational purposes. Buescher (2010) stated that Edmodo was an educational software that enabled students and teachers to participate in micro-blog discussions, respond to and manage questionnaires, and present assignments. Noviana, Rufinus and Bunau (2015) conducted a pre-test and post-test study in order to determine the improvement in the writing skills of high school students that used Edmodo. The conducted study included 29 students. The authors indicated that the students received a total score of 1240 and an average score of 42.76 for the pre-test and such scores were described as poor. In the study, the total score of the students was 2030 and the average score was 70 . However, the students received a total score of 2030 and an average score of 70 for the post-test and the authors argued that story writing education via Edmodo was highly effective in the increased student achievement. Fauzi (2017) conducted an experimental study with high school students, to determine the effects of Edmodo use and concluded that using Edmodo facilitated a safe online environment, both for the students and the teachers, to carry out a more effective and sustainable teaching and learning process. Ramdhani (2017) used Edmodo to evaluate the academic paragraph writing skills of prospective English teachers and stated that using Edmodo was useful in developing the paragraph writing skills of the students. Doğan (2019) studied the effects of Edmodo use on the English writing skills of university level English preparatory class students. The findings of the study indicated that the majority of the participants were satisfied with Edmodo, appreciated using Edmodo for English writing classes, and that it was more pleasant to write English via Edmodo. Other significant findings pointed out that the participants believed their writing skills developed via Edmodo use, that the students appreciated collaborative writing activities and the availability of works and course materials in Edmodo facilitated selfobservation of progress for the students.

The content of Turkish Language II courses in faculties of education focuses on academic writing instruction. Turkish Language II is a three hour per week course. Especially in populated classrooms, three hours per week might not be sufficient to present the related theoretical information and to ensure student acquisition of the subjects, thus, the students could be challenged in turning the new knowledge into a skill. Therefore, it was considered that a course conduct and interactive participation of students, 
assisted via Edmodo use could be beneficial. Literature review returned no studies that focused on the use of technology in the Turkish Language II courses, offered in faculties of education. Therefore, the present study was intended both to point out the aforementioned gap in literature and to provide students with effective and permanent academic writing skills. Based on the significance attributed to the transformation of the achievements of this course, which is an important skill area for the academic careers of the students, into skills, the main problem of the present study is to determine whether technology assisted education contributes to academic writing skills.

\subsection{Research questions}

The aim of the present study is to determine the effects of Edmodo assisted academic writing education on the writing achievement of students. Therefore, the study pursued answers to the following questions:

1. Do academic writing achievements of students differ significantly between the experimental and control groups?

2. What are the student opinions on Edmodo assisted academic writing education?

\section{Method}

Embedded mixed research research, which uses both quantitative and qualitative data, was employed in the present study. "In this research design, one of the qualitative or quantitative methods is more central compared to the other. In other words, the research is essentially qualitative or quantitative, however there exists a requirement for alternative methods to support, generalize or explain the obtained data" (Creswell and Plano Clark, 2007). The quantitative data in the present study were obtained by using the Single Group Pretest-Post Test Model. This model suggests that "a group is first subjected to a pre-test measurement, then to an experimental procedure, and finally to a post-test" (Creswell, 2003). Qualitative data were obtained through descriptive and content analysis of semi-structured interview forms and these forms were submitted to students to acquire their written opinions on the Edmodo assisted academic writing education provided during the 14 weeks long Turkish Language II course. Ethical approval for this was not required.

\subsection{Sample / Participants}

The study group consisted of 108 students, 54 in the experimental and 54 in the control group, who were enrolled in the spring semester of the 2018-2019 academic year in the Guidance and Psychological Counseling Program of a state university. Descriptive characteristics of the students who participated the study were presented in Table 1.

Table 1. Descriptive Characteristics of the Students

\begin{tabular}{lllllll}
\hline \multirow{4}{*}{ Gender } & & \multicolumn{2}{l}{ Experimental } & \multicolumn{2}{c}{ Control } & p \\
\cline { 3 - 6 } & & $\mathbf{n}$ & $\mathbf{\%}$ & $\mathbf{n}$ & $\mathbf{\%}$ & \multirow{2}{*}{$\mathrm{X}^{2}=0,370$} \\
& Male & 20 & $\% 37,0$ & 17 & $\% 31,5$ & \\
& Female & 34 & $\% 63,0$ & 37 & $\% 68,5$ & $\mathrm{p}=0,343$ \\
\hline
\end{tabular}

Table 1 indicates that experimental group consisted of 20 male and 34 female students and the control group consisted of 17 male and 37 female students. It was determined that gender distribution was homogenous between groups $\left(X^{2}=0,370 ; p=0,343>0.05\right)$. 


\subsection{Instrument $(s)$}

The quantitative data in the present study were obtained based on the scores, given to the academic texts written by the students within the scope of pre-test and post-test, through the "Academic Writing Evaluation Rubric", developed by Razı (2015).

Semi-structured interview form, the qualitative data collection tool, was submitted to the students due to their signed consent to be used in the present scientific study, in order to obtain student opinions on the Edmodo assisted academic writing education in the Turkish Language II course. Relevant national and international studies in literature, focusing on the use of Edmodo in education, were examined by the authors and the questions of the semi-structured interview form were prepared in order to obtain student opinions on the use of Edmodo in the process of acquiring academic writing skills. The questions were structured in three main classifications, namely, the benefits of Edmodo, recommendations regarding the use of Edmodo and the disadvantages of Edmodo. Expert opinion was received from 5 experts, including 2 measurement and evaluation and 3 field experts. The interview form was finalized based on expert recommendations.

\section{3. Data collection procedures/Implementation steps}

- The research was conducted with students, who were enrolled in the Turkish Language II course during the spring semester of the 2018-2019 academic year.

- Before the course, an Edmodo class, named 'academic writing', was created by the researchers.

- The course contents were explained to the students, parts of an academic article were introduced, and further explanations were presented through example articles at the first lesson of the spring semester. The students were informed that the course would be Edmodo assisted during the semester and were guided for registering with Edmodo. The students were asked to register with Edmodo until the next lesson.

- The researchers confirmed student registrations for Edmodo, articles related to the students' major were uploaded to Edmodo and the students were asked to read the articles before coming to the class.

- In the first lesson of the second week, the lecturer wrote the parts of an article on the board as headings and instructed the students on the issues that they should pay attention to in writing these parts of an article. Subsequently, example parts of the articles uploaded to Edmodo were presented and the parts that were not understood were clarified through question-answer method. A brainstorming activity was carried out on article subjects that the students could write in their area of study. The lesson was finalized asking the students to write an article until the next lesson. It was emphasized that this study would not be graded and would be a used for scientific research, in order to relieve student anxiety related to writing.

- In the following weeks, example articles and various information were shared with the students through Edmodo. Student questions on the course were answered via Edmodo by the lecturer and academic writing education was carried forward through increased communication with the students, in other words Edmodo assisted education.

- Students consulted the lecturer through Edmodo on issues such as method, technique, interview questions, etc., for their final submission of the semester. The instructor provided appropriate feedback to students.

- The book, Turkish Language II Academic Writing Education (2019), edited by Mehmet Nuri Kardaş and Raşit Koç, was used and during the course, the students were instructed for all phases of academic writing and asked to employ these phases in their studies. 
- The course process covered discussions on the articles uploaded to Edmodo and it was ensured that the subjects were comprehended.

- Students transformed everything they learned into a skill and each submitted an article at the end of the semester. Articles written by Edmodo assisted writing education throughout the semester were submitted to the course instructor.

- Each student submitted an original article in the beginning and end of the semester. Those who wished could change the subject of the article they submitted in the beginning of the semester for the end-semester article. The students preferred to work on subjects associated with their field, since they were students in guidance and psychological counseling department. The sample articles supplied for the students in Edmodo also included articles in their field. The article topic was not restricted, it was stated at the beginning of the semester that they could write an article on any subject. In the process, the students consulted with the instructor about the article topic and continued their work based on the provided advice. The lecturer answered the questions of the experimental and control group students about their articles until the end of the semester and tried to ensure that they acquired academic writing skills through continuous feedback and to transfer these skills into behavior. Experimental group students could also consult the instructor via Edmodo. The experiment group students wrote articles on topics such as "Analysis of the movie named "Forrest Gump" based on the cognitive theory," "The analysis of the movie 'Resist!' based on gender inequality," "Expectations of Aydın Adnan Menderes University Students from the university and the satisfaction with their department survey." All articles included secyions that should be present in a scientific study and varied between 4 and 15 pages.

- Student opinions on the use of Edmodo in academic writing education based on the semester were obtained through a semi-structured interview form, due to the written consent of the students.

- The lessons in the control group, which did not receive Edmodo assisted education, were carried out by the same instructor, based on the book, Turkish Language II Academic Writing Education (2019), edited by Mehmet Nuri Kardaş and Raşit Koç.

\subsection{Data analysis}

The quantitative data was analyzed through the scores received for the academic articles of the students, which were submitted as the pre-test and the post-test, and the scores were based on the "Academic Writing Evaluation Rubric", developed by Razı (2015). The quantitative data obtained in the present the study was analyzed using SPSS 22.0 software. The homogeneity of the groups based on gender was tested with chi-square test and the difference between the groups was tested with covariance analysis (ANCOVA) after the difference between the pre-test achievement scores and post-test achievement scores were controlled.

The qualitative data was analyzed through descriptive and content analyses. The written responses of students to the semi-structured interview form were coded over three basic categories and the codings were expressed as numbers and frequencies. Furthermore, the statements written by the students were presented in the Findings section in italics and quotation marks, in order to support the reliability of the study.

\subsection{Validity and Reliability}

Instruction in experimental and control groups was conducted with the aim of the acquisition of the achievements specified in the Council of Higher Education Teacher Training Curriculum by the students. Experimental group included students attending secondary education and control group included students attending primary education. In both experiment and control groups, the courses were 
instructed by the same author. Since the course hours in primary and secondary schools were different, no group interaction problems were experienced.

To ensure the reliability of the quantitative data, scoring was conducted by both authors and an independent expert in Turkish language education. Turkish language education specialist was an academician eployed at a public university, who also wrote a chapter in a book on Academic Writing. After the determination of interrater agreement and disagreement, the formula proposed by Miles and Huberman (1994) was used to determine the agreement coefficient. In this formula, reliability is calculated by multiplying the agreement score by the total of agreement and disagreement and multiplying the result by 100. In the present study, it was determined that the interrater agreement was between. 85 and .100 .

It could be suggested that qualitative data could be considered as evidence that support quantitative data. Throughout the semester, student views on the acquisition of academic writing skills supported by Edmodo shed light on the process. It could be argued that the views of the students that were included in direct quotes in the present study contributed to the reliability of the research.

\section{Results}

\subsection{Quantitative findings of the study}

Descriptive data of the pre- and post-test results based on student achievement in academic writing in the experimental and control groups were presented in Table 2.

Table 2. Mean post-test achievement and adjusted mean post-test achievement scores for the groups

\begin{tabular}{lcccc}
\hline Group & N & Mean & Std. Deviation & Adjusted Mean \\
\hline Experimental & 54 & 81,11 & 22,988 & 86,500 \\
Control & 54 & 60,30 & 20,185 & 54,907 \\
\hline
\end{tabular}

In the present study, the difference between the pre-test achievement scores and post-test achievement scores were controlled and the difference between the groups was tested with ANCOVA (covariance analysis). The significance of the difference between test achievement scores in the two groups was tested with ANCOVA through adjusted means. Prior to the ANCOVA analysis, it was determined that the variances were homogeneous $(\mathrm{p}=0.347>0.05)$; the slopes of the regression lines were found to be equal $(\mathrm{p}=0.369>0.05)$, once the homogeneity of the regressions were tested (group * pre-test achievement).

Table 3. ANCOVA test results for the post-test achievement scores adjusted for pre-test achievement scores

\begin{tabular}{llccccc}
\hline Source of the Variance & Sum of Squares & df & Mean Square & F & p & $\eta^{2}$ \\
\hline Pre-test Achievement & 11718,788 & 1 & 11718,788 & 32,482 & 0,000 & \\
Group & 21259,119 & 1 & 21259,119 & 58,926 & 0,000 & 0,359 \\
Error & 37881,804 & 105 & 360,779 & & & \\
Total & 601192,000 & 108 & & & & \\
$\mathrm{R}^{2}=0,382$ (Adjusted $\left.\mathrm{R}^{2}=0,370\right)$ & & & & & \\
\hline
\end{tabular}

The difference between the adjusted post-test achievement scores was significant $(\mathrm{F}=0,058$; $\mathrm{p}=0,000<0,05)$, based on the results of the Ancova analysis. The complementary test indicated that the experimental group presented higher achievement when compared the control group. 


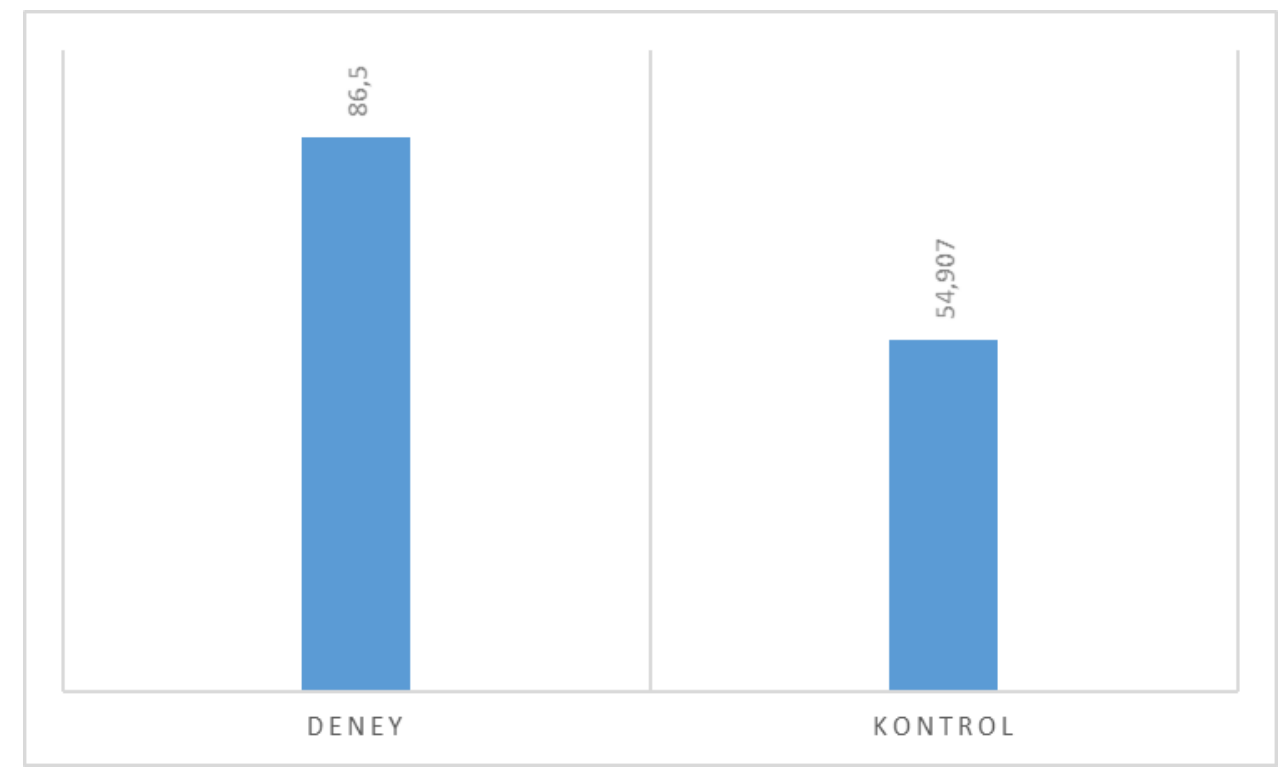

Figure 1. Adjusted Mean Post-test Achievement

\subsection{Qualitative findings of the study}

In the present study, written student opinions on using Edmodo in the process of gaining academic writing skills were retrieved with a semi-structured interview form. Three main categories were identified based on the results of the content analysis applied to these forms: "positive effects of Edmodo in academic writing education", "recommendations for a more effective use of Edmodo in academic writing education" and "negative aspects of using Edmodo in academic writing education". The codes were created over the abovementioned categories and were specified as numbers and percentages. Student opinions were presented in Table 4.

Table 4. Student opinions on using Edmodo in academic writing education

\begin{tabular}{|c|c|c|c|}
\hline Category & Code & Number & Frequency \\
\hline \multirow{7}{*}{\begin{tabular}{lr}
\multicolumn{2}{l}{ Positive effects of } \\
Edmodo in \\
academic writing \\
education
\end{tabular}} & $\begin{array}{l}\text { Access to accurate information and benefit of articles } \\
\text { uploaded as examples }\end{array}$ & 49 & $90 \%$ \\
\hline & $\begin{array}{l}\text { Effective and rapid communication between the } \\
\text { instructor-student and student-student }\end{array}$ & 45 & $83 \%$ \\
\hline & Increased interest in class & 44 & $81 \%$ \\
\hline & Effective, easy and permanent learning & 43 & $79 \%$ \\
\hline & Facilitated follow-up and preparedness for the course & 40 & $74 \%$ \\
\hline & $\begin{array}{l}\text { Easy access to and immediate feedback from the } \\
\text { instructor }\end{array}$ & 28 & $51 \%$ \\
\hline & Easy access to information & 18 & $33 \%$ \\
\hline $\begin{array}{l}\text { Recommendations } \\
\text { for a more }\end{array}$ & $\begin{array}{l}\text { There should be more interaction; suggestions such as } \\
\text { poetry, books etc. should be offered. }\end{array}$ & 27 & $50 \%$ \\
\hline $\begin{array}{lll}\text { effective } & \text { use } & \text { of } \\
\text { Edmodo } & \text { in }\end{array}$ & $\begin{array}{l}\text { Course content could be endorsed with images and } \\
\text { videos and examples could be increased }\end{array}$ & 14 & $25 \%$ \\
\hline academic writing & Should be applied to other courses as well & 7 & $12 \%$ \\
\hline education & $\begin{array}{l}\text { Notes on the topics covered in the course should be } \\
\text { uploaded to the system and discussion should be } \\
\text { provided via Edmodo }\end{array}$ & 3 & $5 \%$ \\
\hline
\end{tabular}




\begin{tabular}{|c|c|c|c|}
\hline \multirow{8}{*}{$\begin{array}{l}\text { Negative aspects } \\
\text { of using Edmodo } \\
\text { in academic } \\
\text { writing education }\end{array}$} & The program language should be Turkish & 2 & $3 \%$ \\
\hline & $\begin{array}{l}\text { Sources of the course should be uploaded based on the } \\
\text { economy principle }\end{array}$ & 1 & $1 \%$ \\
\hline & English program language & 25 & $46 \%$ \\
\hline & Complexity of the program & 10 & $18 \%$ \\
\hline & Forgetting user password & 2 & $3 \%$ \\
\hline & No Internet access & 2 & $3 \%$ \\
\hline & $\begin{array}{l}\text { Anxiety that the questions asked would be seen by other } \\
\text { students }\end{array}$ & 2 & $3 \%$ \\
\hline & Smart phone requirement & 1 & $1 \%$ \\
\hline
\end{tabular}

Table 4 indicates that positive student opinions on the use of Edmodo in the process of academic writing education were prevalent. Several student opinions regarding the benefits of Edmodo were expressed as follows: (Students were named with the codes that directly relate to quantitative data.)

S.25. "Shared content in Edmodo helped us through examples, reading examples about our assignment provided me information about the subject. I think Edmodo was effective for me to understand the issue better. I think Edmodo helped me a lot in our assignments because we could instantly communicate through Edmodo. Whenever I had a problem, an instant contact with my friend and my teacher helped me to get a rapid information about that problem. And this positively affected my learning."

S.1. "The follow-up was very easy. Because, it is sometimes difficult to follow the lessons in the classroom environment. That's why I find Edmodo as a more comfortable environment. Edmodo has made it easier for me to access information as I never did before, and the fact that there was a discussion environment, in which we could ask the questions that crossed our minds, enabled us to understand the events more easily. As a result, the course became a bit easier. Once the course got easier, my interest in the course automatically increased. So, Edmodo is itself the convenience."

S. 41. "Our teacher shares where we are in the course or the information we need to learn for the next lesson, so we are prepared for the lesson."

S. 31. "As a student of the GC department, I think Edmodo will provide a benefit both for the teacher and the student and if applied to the other courses of the department. Because, as I mentioned before, it ensures that teachers and students are active and in interaction any time."

S. 26. "Edmodo made me feel good because it provided access to information any time. Before this, I never contacted our instructor through any application. Instead of sending a message or mail, it is better to be able to ask anything from this application and get answers in a very short time."

S. 48. "Book recommendations could be given, prize puzzles could be shared, authors could be invited."

S. 32. "I have not noticed a negative situation because we learned so much so far. I believe such applications should be supported."

Several examples for the student opinions on the recommendations for a more effective use of Edmodo in academic writing education were as follows:

S. 13. "It is possible to teach several topics through Edmodo or share more examples on a subject, to make further use of Edmodo. Participants of a classroom could be endorsed for more contribution."

S. 3. "It can be useful in other courses when used as in this course."

S. 42. "I think Edmodo is applicable to every course. It does not matter whether it is verbal or numerical. It is a very good portal for assignment sharing. Teachers can also ask questions. They can create test questions. Students can chat about the course. A virtual course could be taught at a specified time. Edmodo affects the relationship between teacher and student positively." 
S. 19. "It can be used more actively through increased class participation, increased sharing, presenting examples and making activities."

Examples for the student opinions on the negative aspects of using Edmodo in academic writing education were as follows:

S. 29. "It is a negative aspect that the application is in English."

S. 23. "Language option should be introduced."

S. 45. "In the first use, the student may feel strange and unfamiliar."

S. 53. "It is a trouble if you forget your password."

S. 37. "There might be situations where there's no internet access, such as dormitories."

S. 47. "The fact that everyone sees your questions could make one feel anxious."

S. 8. "The application was a bit complex."

The qualitative results of the study suggested that the students considered Edmodo use in academic writing education useful. Students indicated that they were able to acces the correct information with Edmodo, the example articles they accessed through Edmodo were useful, that Edmodo provided rapid communication between the instructor-student and student-student, increased the interest in the course, provided effective, easy and permanent learning, facilitated the course follow-up, preparedness for class, teacher accessibility and feedback and ease of access to information.

Students recommended increased interaction among students, poetry, books, etc., images and videos to support the course contents, increased number of examples, application in other courses, uploading the notes on the topics covered in the formal course to the system, conducting discussion sessions on Edmodo, Turkish language support and uploading the sources used during the course to the system for a more effective use of Edmodo in academic writing education.

Students indicated that the negative aspects of Edmondo assisted academic writing education were English as the program language, complexity of the program, forgetten user password, no Internet access, anxiety that the questions that were asked the instructor would be seen by other students and requirement for a smart phone.

\section{Discussion}

The present study established that Edmodo assisted academic writing education significantly contributed the students in acquiring academic writing skills. A significant difference was determined between the adjusted post-test achievement scores between the groups, based on ANCOVA analysis $(\mathrm{F}=0,058 ; \mathrm{p}=0,000<0,05)$. The experimental group had a higher achievement compared to the control group based on the results of the complementary test. Tuzlukova, Busaidi, Coombe and Stojković (2016) indicated that online learning environments improved skills in writing, working and computer literacy. The findings of this study presented similarities with various studies that indicated using Edmodo in writing education increased student achievement (Noviana, Rufinus and Bunau, 2015; Fauzi, 2017; Ramdhani, 2017; Doğan, 2019). Parallel to the findings of the present study, Ma'azi and Janfeshan (2018) established that the Edmodo social learning network had significant effects on the writing skills of Iranian students, who were learning English as a foreign language and that the students had positive opinions on the use of Edmodo social network in their courses.

Qualitative findings also indicated that Edmodo use was beneficial. Students stated that the ability to access correct information, the usefulness of the example articles they accessed through Edmodo, rapid communication between the instructor-student and student-student, increased interest in the course, 
effective, easy and permanent learning, facilitated the course follow-up, preparedness for class, teacher accessibility and feedback and ease of access to information were the positive effects of Edmodo assisted academic writing education. Correspondingly in literature, Purnawarman, Susulavati, and Sundayana (2016) concluded that the use of Edmodo in writing facilitated cognitive involvement of the students. Similar findings to the findings of the present study were found in the study conducted by Hamutoğlu and Kiyıc1 (2017), in which 37 first-year students of the faculty of education enrolled in the new literacy course presented their views on the use of Edmodo. The study reported that Edmodo was considered a useful and effective social network used for educational purposes in accordance with content and information exchange in a course; it increased attention on the course; the use of Edmodo in the new literacy course provided a significant social and cognitive effect when considered within the scope of new literacy skills. Students who participated the study indicated that peer opinions on a subject contributed own learning, developed own ideas and stated that they could access the course content practically anywhere when using Edmodo.

Student recommendations regarding a more effective use of Edmodo in academic writing education included increased interaction among students, poetry, books, etc., images and videos to support the course contents, application in other courses, uploading the notes on the topics covered in the course to the system, facilitating a discussion environment, Turkish language support and uploading the sources used during the course to the system in correspondence with the principle of economy.

The negative aspects of Edmondo assisted academic writing education were reported as follows: English as the program language, complexity of the program, forgetten user passwords, requirement for a smart phone, problems with Internet access and anxiety that the questions that were asked would be seen by other students. In a study conducted by Hamutoğlu and Kıyıc1 (2017), the inadequacy of Turkish language support was stated as one of the limitations of the system. Dewi (2014) also described the problems in using Edmodo as low level of computer literacy and lack of access to computers and/or internet. The findings of the present study correspond with the findings of Dewi (2014), given the requirement for a smart phone and problems with internet access.

In general, the findings of the present study, based both on quantitative and qualitative data, revealed that the use of Edmodo in academic writing education was highly useful. Writing education requires a process-based, meticulous and a careful training. Bağc1 Ayranc1 and Mete (2017, p. 1254) stated that the instructor was a guide at every stage of the process-based writing education, that the individual differences of the students were taken into consideration and writing was not only considered as a classroom activity. Given such information and research findings, it is possible to state that writing education is not only an in-classroom activity and it would be beneficial to assist writing education via Edmodo outside the classroom.

In this respect, following suggestions could be made in order to disseminate Edmodo-assisted education in the Turkish Language II courses, which require substantial knowledge and skills, such as academic writing:

1- Technology-assisted education attracts the students' attention more due to the technological developments of the current era and leads to a more effective learning. Therefore, a more attractive use of and increased student communication over Edmodo could positively contribute the course achievement scores or attendance of studens based on their active involvement in Edmodo.

2- Access points and computers could be readily available, with the intent to eliminate technological difficulties that could be experienced by the students.

3- Several elective courses, based on student preferences, could be provided through applications as Edmodo. 
4- Applied courses that do not solely consist theoretical knowledge and rather has to be transformed into skills could be supported by applications such as Edmodo.

5- Educators could receive in-service training on applications such as Edmodo

6- An extensive knowledge on educational applications such as Edmodo could be beneficial for students, especially for prospective teachers, since they would be able to utilize such applications in their own courses in the future.

7- Turkish could be introduced as an optional language for such applications offered in English and the necessary studies could be conducted by the universities.

8- Joint courses at international level could be conducted through programs such as Edmodo, with multinational participation.

9- Parent notifications on course follow-ups could be used more effectively with applications as Edmodo.

10- The communication process in the Edmodo program could be more active by assigning more than one instructor to a course.

\section{Conclusions}

The present study established that Edmodo assisted academic writing education significantly contributed the students in acquiring academic writing skills. A significant difference was determined between the adjusted post-test achievement scores between the groups, based on ANCOVA analysis $(\mathrm{F}=0,058 ; \mathrm{p}=0,000<0,05)$. The experimental group had a higher achievement compared to the control group based on the results of the complementary test.

Qualitative findings also indicated that Edmodo use was beneficial. Students stated that the ability to access correct information, the usefulness of the example articles they accessed through Edmodo, rapid communication between the instructor-student and student-student, increased interest in the course, effective, easy and permanent learning, facilitated the course follow-up, preparedness for class, teacher accessibility and feedback and ease of access to information were the positive effects of Edmodo assisted academic writing education.

The negative aspects of Edmodo assisted academic writing education were reported as follows: English as the program language, complexity of the program, forgetten user passwords, requirement for a smart phone, problems with Internet access and anxiety that the questions that were asked would be seen by other students.

\section{Ethics Committee Approval}

The authors confirm that this study does not need ethics committee approval.

\section{Acknowledgements}

**The present study was based on the proceeding presented in 6th Global Conference on Contemporary Issues in Education, organized in St. Petersburg on August 29-31, 2019.

The study was sponsored by 2224-A International Scientific Activities Participation Support Program by TUBITAK. 


\section{References}

Ali, Z. (2015). A case study of tertiary students' experiences using edmodo in language learning. The International Journal of Language Education and Applied Linguistics (IJLEAL), 2, 39-48.

Altunkaya, H. (2019). Akademik metin yazmanın basamakları-III: Giriş bölümü hazırlama (Steps in academic manuscript writing - III: Writing the Instroduction). Mehmet Nuri Kardaş ve Raşit Koç (Editors), in Türk Dili II Akademik Yazma Eğitimi (pp. 133-150). Ankara: Pegem Akademi Yayıncilik.

Arneback, E. Englund, T. \& Solbrekke, T. D. (2016). Writing in and out of control: A longitudinal study of three student teachers' experiences of academic writing in preschool teacher education. Nordic Studies in Education, 36, 211-228

Bağc1 Ayranc1, B. \& Mete, F. (2017). Evaluation of teacher candidates writing skills. Educational Research and Reviews, 12(24), 1253-1259, DOI: 10.5897/ERR2017.3430.

Balasubramanian, K., Jaykumar, V. \& Fukey, L. N. (2014). A study on "student preference towards the use of Edmodo as learning platform to create responsible learning environment." Procedia - Social and Behavioral Sciences 144, 416 - 422. Doi: 10.1016/j.sbspro.2014.07.311

Buescher, E. (2010). the wonders of educational blogging. http://coe.winthrop .edu/jonesmg/LTI/2010Fwhitepapers/Eileen_Buescher.pdf

Carolan, F., \& Kyppö, A. (2015). Teaching process writing in an online environment. In J. Jalkanen, E. Jokinen, \& P. Taalas (Eds.), Voices of pedagogical development - Expanding, enhancing and exploring higher education language learning (pp. 13-30). Dublin: Research-publishing.net. doi:10.14705/rpnet.2015.000285

Creswell, J. W. (2003). Research design: Qualitative, quantitative, and mixed methods approaches. Thousand Oaks, CA: Sage.

Creswell, J. W., \& Plano Clark, V. L. (2007). Designing and conducting mixed methods research. Thousand Oaks, CA: Sage

Dewi, F. (2014). Edmodo: A social learning platform for blended learning class in higher education. Research in Education Technology: Pedagogy and Technology Journal, 11(2), 1-11.

Doğan, N. (2019). Işs birlikçi sosyal öğrenme: Üniversite hazırlık öğrencilerine İngilizce yazmayı ögretmede Edmodo'yu sosyal bir platform olarak kullanma (Cooperative social learning: The use of Edmodo as a platform in the instruction of English language writing to prep class college students). Unpublished master's thesis, Pamukkale Üniversitesi, Eğitim Bilimleri Enstitüsü, Denizli.

Fauzi, A. (2017). The effect of Edmodo on students' writing skill in recount text. International Journal of Pedagogy and Teacher Education (IJPTE), 1(2), 73-79.

French, A. (2016). "Fail better": Reconsidering the role of struggle and failure in academic writing development in higher education. Innovations in Education and Teaching International, 55(4), 408416. doi:10.1080/14703297.2016.1251848

Gardner, P. (2014). Becoming a teacher of writing: Primary student teachers reviewing their relationship with writing. English in Education, 48, 128-148.

Hamutoğlu, N. B. ve Kıyıcı, M. (2017). Bir eğitsel sosyal ağ olarak Edmodo'nun yükseköğretimde kullanımına yönelik öğrenci görüşlerinin incelenmesi (The analysis of student views on the use of Edmodo as an educational soical network in tertiary education). Trakya Üniversitesi Eğitim Fakültesi Dergisi, 7(2), 322-343. Doi:10.24315/trkefd.290573 
Kardaş, M. N. ve Koç, R. (2019). Türk Dili II Akademik Yazma Eğitimi (Turkish Language II: Academic Writing Ecucation). Ankara: Pegem Akademi Yayınc1l1k.

Ma'azi, H., \& Janfeshan, K. (2018). The effect of Edmodo social learning network on Iranian EFL learners writing skill. Cogent Education, 5(1), 1-17. doi:10.1080/2331186x.2018.1536312

Miles, M. B. ve Huberman, A. M. (1994). Qualitative data analysis: An expanded sourcebook. London: Sage Publications.

Murray, R., \& Thow, M. (2014). Peer-formativity: A framework for academic writing. Higher Education Research \& Development, 33(6), 1166-1179.

Noviana, O., Rufinus, A., \& Bunau, E. (2015). The effective use of edmodo in writing a narrative text in senior high school. Jurnal Pendidikan dan Pembelajaran, 4(11), 3-16.

Purnawarman, P., Susilawati, \& Sundayana, W. (2016). The use of Edmodo in teaching writing in a blended learning setting. Indonesian Journal of Applied Linguistics, 5(2), 242- 252. Doi: 10.17509/ijal. v5i2.1348.

Ramdhani, A. S. (2017). The use of edmodo as a social media to support the enhancementof students' paragraph writıng skills on the students of first semester of stkıp pancasaktı tangerang. Jurnal Inovasi Pendidikan MH. Thamrin, 1, 7-26.

Raz1, S. (2015). Development of a rubric to assess academic writing incorporating plagiarism Detectors. Sage Open, SAGE Open April-June, 1-13 DOI: 10.1177/2158244015590162 sgo.sagepub.com

Rehberlik ve Psikolojik Danışmanlık Lisans Programı (2018) (Guidance and Psychological Counseling Undergraduate Program). Ankara: Yükseköğretim Kurulu.

Shams-Abadi, B. B., Ahmadi, S. D., \& Mehrdad, A. G. (2015). The effect of Edmodo on EFL learners' writing performance. International Journal of Educational Investigations, 2(2), 88-97.

Stroud, C. (2010). Edmodo: A white paper. Retrieved from http://coe.winthrop.edu/

Tok, M. (2012). Türkçenin yabancı dil olarak öğretiminde akademik yazma becerilerinin geliştirilmesine yönelik uygulamalı bir çalışma (An applied study on the development of academic writing skills in instruction of Turkish as a foreign language). Unpublished dissertation, Çanakkale Onsekiz Mart Üniversitesi, Eğitim Bilimleri Enstitüsü, Çanakkale.

Tuzlukova, V., Busaidi, S. A., Coombe, C., \& Stojković, N. (2016). Research on Technology-based Language Education in the Sultanate of Oman: Perspectives for Student Skills' Enhancement Introduction. The Journal of Teaching English for Specific and Academic Purposes, 4(1), Special Issue, 1-8.

Trust, T. (2012). Professional learning networks designed for teacher learning. Journal of Digital Learning in Teacher Education, 28(4), 133-138. http://doi.org/10.1080/21532974.2012.10784693

Wallace, A. (2014). Social learning platforms and the flipped classroom. International Journal of Information and Education Technology, 4(4), 293-296. DOI: 10.7763/IJIET.2014.V4.416. 


\section{Akademik yazma eğitiminde edmodo kullanımı}

\section{$\ddot{O} \mathbf{z}$}

Akademik yazma, herhangi bir bilim dalında yapılan araştırma raporlarının bilim dünyasına duyurulması amacı ile gerçekleştirilir. Eğitim Fakültelerinin bahar döneminde öğretmen yetiştirme programında yer alan Türk Dili II dersinin içeriği, akademik yazma becerisi öğretimine dayanır. Bu araştırmanın amacı, Edmodo destekli verilen akademik yazma eğitiminin öğrenci başarısı üzerindeki etkisini belirlemektir. Karma araştırma deseni ile yürütülen çalışmada nicel bölüm için ön test-son test kontrol gruplu yarı deneysel desen kullanılmış̧ır. Nitel kısımda ise Edmodo destekli gerçekleştirilen öğretime ilişkin öğrenci görüşleri, yarı yapıladırılmış görüşme formu ile alınmıştır. Araştırmanın çalışma grubunda, bir devlet üniversitesinin birinci sınıfında 2018-2019 eğitim öğretim yılı bahar döneminde öğrenim gören Rehberlik ve Psikolojik Danışmanlık Bölümünden deney grubunda 54 ve kontrol grubunda 54 olmak üzere toplam 108 öğrenci yer almıştır. Nicel verilerin analizi SPSS ile nitel verilerin analizi ise betimsel analiz ile gerçekleştirilmiş̧ir. Nicel analizler neticesinde, deney grubunun kontrol grubuna göre daha yüksek akademik yazma başarısı gösterdiği saptanmıştır. Nitel sonuçlar ise öğrencilerin Edmodo destekli akademik yazma eğitimini yararlı bulduklarını ortaya koymuştur.

Anahtar kelimeler: Edmodo, akademik yazma, öğretmen yetiştirme programı, rehberlik ve psikolojik danışmanlık.

\section{AUTHOR BIODATA}

Hatice Altunkaya received her doctorate degree in İnönü University, Faculty of Education, Department of Turkish Language Education. Her research fields include instruction of Turkish as a native language and as a foreign language. Currently, she works as an associate professor at Aydın Adnan Menderes University, Faculty of Education, Department of Turkish Language Education.

Bilge Ayranc1 completed her PhD at Gazi University Faculty of Education, Department of Turkish Language Education. Her research fields include instruction of Turkish as a native language and writing education. Currently, she works as an associate professor at Aydın Adnan Menderes University, Faculty of Education, Department of Turkish Language Education. 